\title{
Potential of Ulva sp. in biofiltration and bioenergy production
}

\author{
Tiềm năng rong Ulva sp. trong lọc sinh học và sản xuất năng lượng sinh học \\ Research article
}

Dang, Thom Thi ${ }^{1 *}$; Yasufumi, Mishima ${ }^{2}$; Dang, Kim Dinh ${ }^{1}$

${ }^{1}$ Department of Hydrobiological Environment, Institute of Environmental Technology, Vietnam Academy of Science and Technology, 18 Hoang Quoc Viet,,Hanoi, Vietnam; ${ }^{2}$ Biomass Technology Research Center, National Institute of Advanced Industrial Science and Technology, Hiroshima, 739-0046 Japan

\begin{abstract}
In order to evaluate the effect of seaweeds in bio-filtration for removing nitrogen from marine aquaculture and in bioenergy production, Ulva sp. was used in this study. Experiments were triplicated and run in 3-day incubation at salinities with $30 \mathrm{psu}, 10 \mathrm{psu}$ and $5 \mathrm{psu}$ in different initial ammonium nitrogen concentrations from $100 \mu \mathrm{M}$ to $10,000 \mu \mathrm{M}$, equivalently to marine aquaculture conditions. The highest concentrations of ammonium removed were about $690 \mu \mathrm{mol}(12.42 \mathrm{mg})$ $\mathrm{NH}_{4}{ }^{+}$at $30 \mathrm{psu}, 410 \mu \mathrm{mol}(7.38 \mathrm{mg}) \mathrm{NH}_{4}{ }^{+}$at $10 \mathrm{psu}$ and $350 \mu \mathrm{mol} \mathrm{NH}{ }_{4}^{+}\left(6.3 \mathrm{mg} \mathrm{NH}_{4}^{+}\right)$at 5 psu in three days of incubation, while highest growth rates of Ulva sp. were $49 \%$ and $150 \%$ per day at $500 \mu \mathrm{M}$ of initial ammonium concentration, similarly to the growth rate reported in microalgae. Moreover, after these experiments, biomass of Ulva sp. has been tested for bioenergy producing goals, because the carbohydrate concentration of this alga was very high, reaching $60-70 \%$ of DW. Thus, Ulva sp. can be cultured to remove nitrogen concentration in eutrophication conditions at aquaculture systems in combination with the purpose of bioenergy production after harvesting.
\end{abstract}

Để đánh giá hiệu quả của tảo biển trong việc lọc sinh học loại bỏ hợp chất ni tơ tù việc nuôi trồng thủy sản và trong việc sản xuất năng lượng sinh học, Ulva sp. đã được sủ dụng trong nghiên cúu này. Các thí nghiệm được lặp lại 3 lần và chạy trong 3 ngày trong tủ ổn nhiệt tại các điều kiện độ mặn 30psu, 10psu, 5psu ở các nồng độ $\mathrm{NH}_{4}{ }^{+}-\mathrm{N}$ tù $100 \mu \mathrm{M}$ đến $10.000 \mu \mathrm{M}$, tuơng đuơng với điều kiện nuôi trồng thủy sản nước mặn. Nồng độ cao nhất của $N_{4}^{+}-N$ đuợc loại bỏ khoảng $690 \mu$ mol $\mathrm{NH}_{4}^{+}\left(12,42 \mathrm{mg} \mathrm{NH}_{4}^{+}\right)$tai 30psu, $410 \mu \mathrm{mol} \mathrm{NH}{ }_{4}^{+}\left(7,38 \mathrm{mg} \mathrm{NH}_{4}^{+}\right)$tại 10psu và 350 mmol $\mathrm{NH}_{4}^{+}(6.3 \mathrm{mg}$ $\mathrm{NH}_{4}^{+}$) tại $5 \mathrm{psu}$, trong đó tỉ lệ sinh truởng của Ulva sp. là rất cao, sinh truởng tù 49 đến $150 \%$ mỗi ngày tại nồng độ ammonium ban đầu $500 \mu M$ tuơng đưong với sinh truởng của vi tảo. Hơn nũa, sau các thí nghiệm trên, sinh khối của Ulva sp. được thủ nghiệm sản xuất năng luợng sinh học vì hàm luọng carbohydrate trong tảo rất cao, chiếm khoảng 60-70\% trọng luọng khô của tảo. Nhu vậy, Ulva sp. có thể được nuôi trồng để loại bỏ hợp chất ni tơ trong điều kiện phú duõng của các hệ thống nuôi trồng thủy sản, kết hợp với mục tiêu sản xuất năng lượng sinh học sau thu hoạch.

Keywords: Ulva sp., biofiltration, aquaculture, bioenergy production

\section{Introduction}

There are many worldwide interests in the potential of microalgae and macroalgae in bioenergy production, particularly for oil and biodiesel production. The potential of bioenergy resources from macroalgae relates to that of alga feedstock. This was evaluated by growth rate of alga biomass in optimal conditions. In the Southeast Asia area, macroalgae which are the available resources in the brackish or marine medium need to be studied deeply as a strategy of sustainable environmental protection. Many species of macroalgae such as Ulva sp., Gracilaria sp.,
Porphyra sp. have been studied as object for biofiltration in eutrophicated water of aquaculture (Pedersen, 2004; Zhou et al. 2006; Kang et al. 2011; Dong Xu et al. 2011).

Macroalgae are considered as potential materials for biofuel production, because they have high carbohydrate content suitable for transformation processes into bioethanol and other products (Reith et al., 2005). Macroalga utilization offers many benefits by enhancing economic production through mitigation of eutrophication in aquaculture ponds and using harvested biomass for bioenergy. In the present study, we estimated the growth rate of macroalga Ulva sp. under laboratory conditions for re- 
moving nitrogen from eutrophic water equivalent to polluted aquaculture conditions and we evaluated the potential of bioenergy production from this algal biomass.

\section{Materials and Methods}

Ulva sp., classified as Enteromorpha sp. before, was collected from the Ishigaki-Jima Island, Okinawa Prefecture, Japan and cultured in IMK medium for microalgae (Nihon-Seiyaku Co., Ltd). The seawater taken from Hiroshima Bay, Seto Inland Sea, Japan and filtered by $0.45 \mu \mathrm{m}$ membrane filter was used for preparing the culture medium. The filtered seawater of Hiroshima Bay was diluted by distilled water at $30,10,5 \mathrm{psu}$, and the modified IMK medium and $\mathrm{K}_{2} \mathrm{HPO}_{4}$ solution were added, so the final concentration of DIP was $30 \mu \mathrm{M}$. The initial ammonium nitrogen was added like 100, 500, 1000, 2000, 5000 and $10000 \mu \mathrm{M}$ concentrations for $30 \mathrm{psu}$ experiments; 200, $500,1000,2000$ and $5000 \mu \mathrm{M}$ of concentrations for 10 psu experiments; 200, 500, 1000, 2000 and $5000 \mu \mathrm{M}$ for 5 psu experiments, respectively.

About 0.11-0.35 g of wet weight alga was taken, depending on each batch of experiments. All batches of experiments were inoculated in $2 \mathrm{~L}$ plastic bottles with $1.8 \mathrm{~L}$ of the culture medium. All tanks were incubated at $25^{\circ} \mathrm{C}$, with light intensity of $800 \mu \mathrm{mol} / \mathrm{m}^{2} / \mathrm{s}$ where the L: D is 14 $\mathrm{h}: 10 \mathrm{~h}$, and getting bubbled by the air.

The water samples for ammonium nitrogen analysis were collected every 24 hours, and filtered by glass fiber filter (Whatman, GF/F). After a 3-day incubation, the algal biomass was collected and weighted in order to calculate growth rate and to evaluate chemical composition.

Ammonium nitrogen and phosphorus concentrations in the medium were measured by HACH test kit (Hach Co., Ltd). The collected algal biomass was weighted, and the water content of the algae was measured by weight before and after dry-freezing process, following determination of ash content, total nitrogen and total phosphorus concentrations.

The chemical compositions of the algal biomass and monosugar were measured by HPLC method to evaluate the potential for bioenergy production.

\section{Results and Discussion}

\subsection{Growth rate of Ulva sp.}

The growth rates of Ulva sp. in the various salinities, initial $\mathrm{NH}_{4}-\mathrm{N}$ concentrations were different (Figure 1). Growth curves at 30 psu differed from 10 psu and 5 psu and values of growth rates were decreasing gradually whereas initial ammonium concentrations were increased. Initial ammonium of $500 \mu \mathrm{M}$ was the best condition for growth of Ulva sp. at 30 psu and 10 psu experiments, in which the growth rate of the algae was extremely high, reaching about $149 \%$ and $49 \%$ /day, respertively.

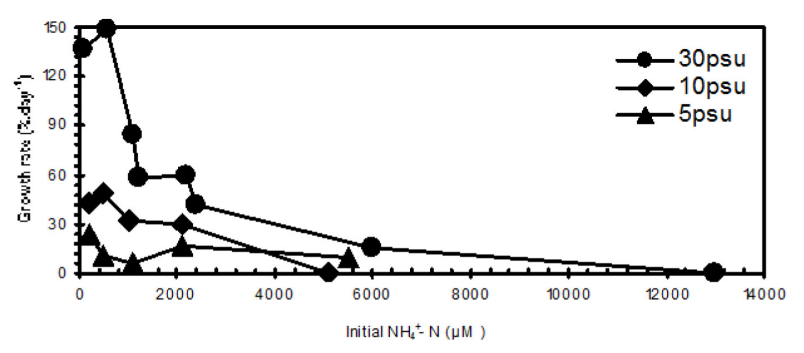

Figure 1. The growth rate of Ulva sp.

The growth rate of Ulva sp. tended to decrease when initial ammonium concentration was increased, and salinity was decreased. The Ulva sp. can grow even in conditions of 2,000 to $5,000 \mu \mathrm{M}$ of initial ammonium concentrations, which is an extremely high ammonium concentration. They can not grow at $10,000 \mu \mathrm{M}$ of initial high ammonium concentration at $30 \mathrm{psu}$. With 2,000 and 5,000 $\mu \mathrm{M}$ of initial ammonium concentrations in $30 \mathrm{psu}$ experiments, the growth rates of Ulva sp. were $42 \%$ and $16 \%$ per day, respectively.

In low salinity concentrations, at 10 and 5 psu experiments, the growth rates were lower than that in higher salinity. However, Ulva sp. can still grow in 5,000 $\mu \mathrm{M}$ of initial ammonium concentrations from 5 to 30 psu experiments. It should be noted that growth rates of some other macroalga species (E.Msuya, Amir Neori, 2000) were lower than that of Ulva sp. cultured in this experiments. Growth rates of Ulva reticulata, Gracilaria crassa, Chaetomopha crassa in E.Msuya's research were from 0,5 to $3 \%$ per day. Growth rate of Ulva lactuca (Pedersen and Borum, 1996) reached up to $30 \%$ /day in northern temperate regions. It was proved that growth rates of Ulva sp. in various initial $\mathrm{NH}_{4}^{+}-\mathrm{N}$ concentrations at $30 \mathrm{psu}, 10 \mathrm{psu}$ and 5 psu were extremely high, and the highest growth rate in $500 \mu \mathrm{M}$ of initial ammonium at $30 \mathrm{psu}$ reached $149 \%$ per day. Therefore, Ulva sp. could be suitable for water treatment by ammonium uptake.

\subsection{Ammonium nitrogen uptake rate of Ulva sp.}

Table 1 shows that the capacity of ammonium nitrogen uptake by the algae in a 3-day incubation was extremely high. At the 30 psu experiments with $100 \mu \mathrm{M}$ of initial ammonium nitrogen concentration, ammonium was rapidly removed by the algae. The ammonium nitrogen was uptaken highly in all experiments. Ammonium nitrogen uptake of this alga were $160 \mu \mathrm{mol}$ to $690 \mu \mathrm{mol}$ in 3-day incubation depending on initial ammonium concentrations. 
Table 1. Ammonium nitrogen uptake rate of Ulva sp.

\begin{tabular}{lcc}
$\begin{array}{c}\text { Salinity } \\
(\mathrm{psu})\end{array}$ & $\begin{array}{c}\text { Initial ammonium nitrogen } \\
(\mu \mathrm{M})\end{array}$ & $\begin{array}{c}\text { Uptake rate of ammonium nitrogen } \\
(\mu \mathrm{mol} / 3 \text { days })\end{array}$ \\
\hline & 100 & 310 \\
& 500 & 690 \\
30 & 1,000 & 600 \\
& 2,000 & 600 \\
& 5,000 & 450 \\
\hline & 10,000 & nd \\
10 & 200 & 360 \\
& 500 & 410 \\
& 1,000 & 250 \\
& 2,000 & 360 \\
& 5,000 & nd \\
& 200 & 350 \\
& 500 & 310
\end{tabular}

* nd: not definited

Figure 2 demonstrates the ammonium nitrogen uptake rates of Ulva sp. At 30 psu experiment, capacity of ammonium nitrogen uptake of this alga was highest, about 4$5 \mathrm{mmol} / \mathrm{g}$ initial wet weight in 3-day incubation. This was equivalent to about $64-70 \mathrm{mg}$ ammonium removed by one gram of algal wet weight in 3-day incubation. However, at $10 \mathrm{psu}$ and $5 \mathrm{psu}$ experiments, ammonium uptake of Ulva sp. was smaller, about $1 \mathrm{mmol} / \mathrm{g}$ initial wet weight in 3-day incubation. In this condition, value of ammonium uptake of Ulva sp. was also high.

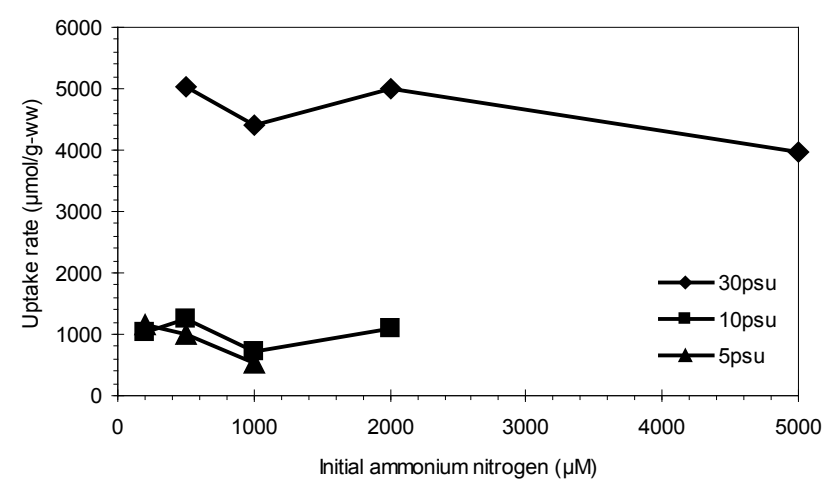

Figure 2. Uptake rate of ammonium nitrogen ( $\mu$ mol/3days).

There are many factors influencing the growth rate of green algae and their removing ability for nutrients like physical condition ( $\mathrm{pH}$, salinity, temperature, etc.) and chemical condition (nutrients, metals, etc.) in cultivation media. However, nitrogen and phosphorus were two main nutrients that limit algal growth and yields in most natural environments (Harrison and Hurd, 2001). Nitrate and ammonia were important available nitrogen sources for growth of seaweeds. After these ions are absorbed from the environment, they are generally incorporated into amino acid and proteins, or used in the synthesis of pigments such as phycoerythrin, which is considered to be a store of available nitrogen (Lapoine, 1985; Ryther et al.,
1981). However, in many types of seaweeds, nitrogen in the form of ammonium was frequently absorbed and assimilated more rapidly than nitrate and urea (De Boer, 1981). In this report, the carried out experiments showed that capacity of $\mathrm{NH}_{4}^{+}$uptake was very good by Ulva sp. in different salinities.

In general, ammonium uptake rates of Ulva sp. were different depending on initial $\mathrm{NH}_{4}-\mathrm{N}$ concentrations and sanilities. In media with initial high concentrations of ammonium $(5,000 \mu \mathrm{M}$ and $10,000 \mu \mathrm{M}), \mathrm{NH}_{4}^{+}$uptake by Ulva sp. was limited. In initial lower concentrations of ammonium, (500 $\mu \mathrm{M}$ to $2000 \mu \mathrm{M})$, nutrient uptake by the alga was very good at different salinities.

\subsection{Chemical composition of Ulva sp.}

After experiments, water content of the alga was determined. Water contents in almost of the algal samples were very high, about from $80 \%$ to $92 \%$, depending on initial conditions of culture. Phosphorus content of the algal biomass was about from $0.1 \%$ to $1 \%$ depending also on initial experimental conditions. The obtained data showed that phosphorus contents were higher in Ulva sp. cultured in conditions of lower salinity (These values were from $0.1 \%$ to $0.3 \%$ at $30 \mathrm{psu}$, from $0.59 \%$ to $0.78 \%$ at $10 \mathrm{psu}$ and about $1 \%$ at $5 \mathrm{psu}$ ).

The data about ash, protein and carbohydrate $(\mathrm{C}-\mathrm{H})$ contents of Ulva sp. biomass presented in Table 2 showed that they changed depending on the initial ammonium concentrations and salinities. 
Table 2. Chemical composition of Ulva sp.

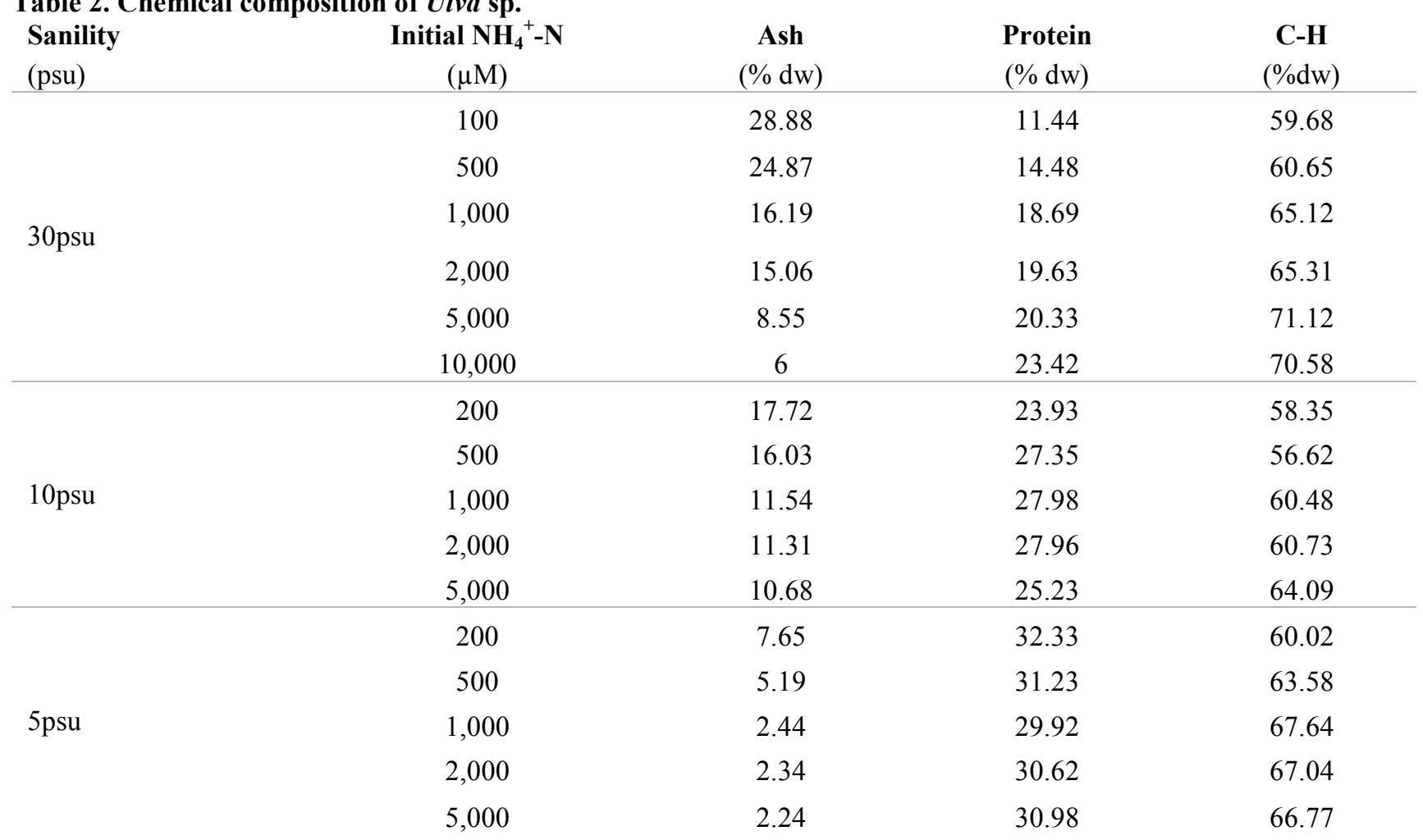

In general, carbohydrate content containing $60-70 \%$ of DW increased a little, while the ash content decreased indicating advantages of this alga species serving as a source for producing biofuel.

\section{Conclusions}

The green alga Ulva sp. can be cultured, and survived in medium having high ammonium concentration and showed quickly growth rate from $6 \%$ to $149 \%$ per day.

The obtained results indicated that Ulva sp. could be useful for nitrogen removing as biofiltration with 690 $\mu \mathrm{mol}(12.42 \mathrm{mg}) \mathrm{NH}_{4}^{+}$at $30 \mathrm{psu}, 410 \mu \mathrm{mol}(7.38 \mathrm{mg})$ $\mathrm{NH}_{4}{ }^{+}$at $10 \mathrm{psu}$ and $350 \mu \mathrm{mol}(6.3 \mathrm{mg}) \mathrm{NH}_{4}{ }^{+}$at 5 psu in 3day incubation. Moreover, it's biomass could be a suitable source for bioenergy production because of the very high content of carbohydrates (60-70\% of DW).

So, the nutrient uptake ability of the alga combined with its biomass after harvesting for potential energy production may offer an economically viable solution for sustainable development.

\section{Acknowledgement}

This work was supported by the fund from New Energy Foundation - Japan. The author would like to thank NEF and to acknowledge to National Institute of Advanced Industrial Science and Technology (AIST) Chugoku, Biomass Technology Research Center for providing research facilities.

\section{References}

[1] Mansilla, A., Palacios, M., Navarro, N.P., Avila, M.
2008. Growth and survival performance of the gametophyte of Gigartina skottsbergii (Rhodophyta, Gigartinales) under defined nutrient conditions in laboratory culture. J Appl Phycol: 889-896.

[2] Demirbas, A. 2010. Use of algae as biofuel sources, Sila Science, Trabzon, Turkey, Energy conversion and Management: 2738-2749.

[3] Randall, D.J., Tsui, T.K.N. 2002. Ammonia toxicity in fish. Marine Pollution Bulletin: 17-23.

[4] Xu, D., Gao, Z., Zhang, X., Qi, Z., Meng, C., Zhuang, Z., Ye, N. 2011. Evaluation of the potential role of the macroalgae Laminaria japonica for alleviating coastal eutrophication. Bioresoure Technology 102(2011): 9912-9918.

[5] Msuya, F.E., Neori, A. 2002. Ulva reticulata and Gracilaria crassa: Macroalgae that can biofilter effluent from tidal fishponds in Tanzania. Western Indian Ocean J.Mar.Sci. Vol.1, No.2: 117-126.

[6] Park, J.I., Lee, J.W., Sim, S.J., Lee, J.H. 2009. Production of Hydrogen from marine macro-algae biomass using anaerobic sewage sludge microflora. Biotechnology and Bioprocess Engineering, 14:307315.

[7] Hronrich, J.E., Martin, L., Plawsky, J., Bungay, H.R. 2008. Potential of Eichhornia crassipes for biomass refining. J. Ind Microbiol Biotechnol 35:393-402. DOI 10.1007/s10295-008-0333-x.

[8] Adams, J.M., Gallagher, J.A., Donnison, I.S. 2009. Fermentation study on Saccharina latissima for bioethanol production considering variable pretreatment. J. Appl Phycol 21:569-574, DOI 10.1007/ s10811-008-9384-7.

[9] Pedersen, G., Kraemer, C.Y., Yarish, C. 2004. The 
effect of temperature and nutrient concentrations on nitrate and phosphate uptake in different species of Porphyra from Long Island Sound (USA). J.Exp.Mar.Biol.Ecol.312, 235-252.

[10] Mishima, Y., Isa, A., Dang, T.T., Nguyen, H.T., Minowa, T. 2009. Potential of bioenergy production from green macroalgae, and mitigation of water environment. Renewable energy 2010 Proceeding,
Pacifico Yokohama, Yokohama, Japan. P-Bm-47.

[11] Zhou, Y., Yang, H.S., Hu, H.Y., Liu, Y., Mao, Y.Z., Zhou, H., Xu, X.L., Zhang, F.S. 2006. Bioremediation potential of the macroalgae Gracilaria lemaneiformis (Rhodophyta) integrated into fed fish culture in coastal waters of north China, Aquaculture 252, 264-276. 